\title{
Narco-Messages: Competition and Public Communication by Criminal Groups
}

\author{
Brian J. Phillips \\ University of Essex and Centro de Investigación y Docencia Económicas (CIDE) \\ Viridiana Ríos \\ Harvard University
}

\begin{abstract}
Criminal groups often avoid the limelight, shunning publicity. However, in some instances they overtly communicate, such as through banners or signs. We explain the competition dynamics behind public criminal communication, and provide theory and evidence of the conditions under which it emerges. Relying on a new data set of approximately 1,800 banners publicly deployed by Mexican criminal groups from 2007 to 2010, we identify the conditions behind such messaging. The findings suggest that criminal groups "go public" in the presence of interorganizational contestation, violence from authorities, antagonism toward the local media, local demand for drugs, and local drug production. Some of these factors are only associated with communication toward particular audiences - rivals, the state, or the public. Interestingly, we find that the correlates of criminal propaganda are sometimes distinct from those of criminal violence, suggesting that these phenomena are explained by separate dynamics.
\end{abstract}

Keywords: Organized crime, communication, Mexico 
Why do criminal groups sometimes use public communication to overtly transmit information to their rivals, the government, or even the general public? This kind of behavior is puzzling because criminal groups are often said to avoid the limelight, shunning publicity to avoid government attention. One key distinction the literature makes between criminal groups, and more "political" groups such as rebels or terrorists, is their level and type of public communication, particularly with the government and public. ${ }^{1}$ Perhaps because of the intriguing nature of criminal group public communication, a growing body of research seeks to understand it (Atuesta 2016, Campbell 2014, Décary-Hétu and Morselli 2011, Durán-Martínez 2015a, Ríos and Rivera 2018, Ríos and Ferguson 2019). ${ }^{2}$ However, questions remain as to why it occurs at all.

This paper builds an argument for why we sometimes see criminal groups publicly communicating, but more often do not. We draw on the literature on organized crime, and on research about other types of violent groups, such as insurgents and terrorists. Important distinctions exist between these groups and criminal organizations (e.g., Phillips 2015, Campbell and Hansen 2013), but work on the value of information in insurgency and the signaling nature of terrorism help explain criminal communication. We argue that in competitive conditions, the value of public communication is especially high, and therefore such information-sharing by criminal groups should be likely. Public criminal communication should be likely when there is: antagonism among criminal groups, government crackdowns, what we call "information competition" with the news media, local drug consumption, and local drug production. Furthermore, we argue that some of these factors should be especially associated with communication toward particular audiences: other criminals, the state, or the public. 
Empirically, we analyze a prominent recent type of criminal communication, the deployment of "narco-messages" ${ }^{3}$ during the early years of the militarized drug-related conflict in Mexico. The violence has led to more than 100,000 deaths, and tens of thousands of citizens have gone missing. Researchers seek to understand the levels of violence in Mexico (Osorio 2015; Calderón et al 2015; Ríos 2013, 2014, 2015; Trejo and Ley 2018), but far less work analyzes dynamics within the conflict such as communication strategies. Criminal messages in Mexico are fascinating in their own right, and are an example of a phenomenon that has occurred around the world, in places such as Colombia, Southern Italy, and U.S. cities (Coleman 1990, Carbray 2002, Ortiz 2013). Research on such communication is important for understanding criminal violence and its consequences.

To create the dependent variable of this study, we generated a data set of about 1,800 narco-messages found in Mexico during 2007-2010. ${ }^{4}$ These publicly deployed banners allow criminal groups to take credit for their criminal actions, intimidate other potential victims, communicate with public, or threaten police or journalists. This dataset of narco-messages is likely to be useful to scholars of criminal violence, as well as those seeking to understand differences and overlaps between criminal and more political violence. We also introduce new data on drug consumption in Mexican municipalities, based on drug-related medical emergencies.

The next section discusses research on information and public communication by violent groups. We then present our argument, with relevant hypotheses. The third section presents original data and describes empirical tests and results. In general, we find that competitive environments are far more likely to produce public criminal 
communication. Examining the intended audiences of narco-messages provides additional nuanced evidence. Messages targeting authorities were more likely after government attacks on criminal groups, for example, and messages targeting the public were more likely after criminal attacks on journalists. We conclude by discussing how the paper contributes to the literature, and consider possible steps for future research.

\section{Information, public communication, and organized crime messages}

Information plays an important role in the study of subnational violence, such as civil conflict. Kalyvas's (2006) explanation of civil war hinges on actors seeking information, and argues that selective violence in particular depends on private information. It is also crucial for participants in violent situations to share information. For insurgents, communication can be crucial to get the public on their side, threaten the government, to share information with other insurgents, and lobby foreign capitals (Coggins 2015, Huang 2016). Information provision is also a major part of terrorism, which has been described as violent propaganda or violent communication (Schmid and de Graaf 1982). Terrorist groups sometimes claim their attacks, for reasons including intergroup competition (Hoffman 2010) and communication within the group (Brown 2017). There are also reasons militant groups do not claim attacks, for example to avoid a bad reputation (Kearns et al. 2014, Abrahms and Conrad 2017).

As with insurgent or terrorist violence, in organized crime information provision is also critical. All sides of the "conflict" have information they want to share.

Governments threaten groups, try to entice group members to collaborate, and try to encourage to witnesses to testify. Civilians caught in the middle sometimes try to publicly 
relay information as well, for example holding protests against organized crime (Cowell 1992; Ferrarin 2011). Beyond governments and the public transmitting message about organized crime, criminals of course are often purveyors of information as well.

\section{Criminal groups and public communication}

We use the term "criminal group" for any collective of individuals dedicated to illicit activity. This is a broad understanding (cf. Varese 2010), but consistent with other authors and institutions (e.g., Finckenauer 2005; United Nations 2004). This term includes groups from street gangs (which tend to be geographically limited) to mafias (which provide protection) to large trafficking organizations frequently called "cartels." In Mexico, much of the discussion of violence focuses on the latter type of criminal group, the cartels, since they tend to be the most visible (Ríos and Rivera 2018, Ríos and Ferguson 2019). However, smaller groups are increasingly common as the government breaks up the largest cartels (Atuesta and Pérez-Dávila 2018). Additionally, all three types of criminal groups mentioned above have used narco-messages. ${ }^{5}$

Criminal groups communicate with three primary audiences: the government, other criminal groups, and the public. A great deal of criminal group communication is private, as criminals seek to share information while avoiding scrutiny from authorities (Gambetta 2009). However, our focus here is on public communication. This includes billboards, graffiti, banners, speeches to a non-private audience, statements to the news media, tweets, and videos on Youtube (Atuesta 2016, Campbell 2014, Guevara 2013, Décary-Hétu and Morselli 2011, Martin 2012, Womer and Bunker 2010). Public communication presents a key challenge for criminal groups. Given their clandestine 
nature, and illegal nature of their work by definition, the distributors of the information need some degree of anonymity. Even if they use the group's name in the message, they want a way to distribute it without being traced back to specific individuals who could be targeted by authorities. For this reason, public communication by criminal groups is quite different from public communication by licit groups such as political parties or firms.

To publicly communicate while maintaining a degree of secrecy, criminal groups have several options. One is graffiti, which can be done relatively quickly, reducing the chance of detection by authorities, and it is visible to the local community. Criminal groups also use more traditional communication methods. Colombia’s Medellín Cartel issued press releases, such as the one in 1990 pledging not to kill U.S. President George H. W. Bush when he visited (Coleman 1990). More recently, groups use social media (Womer and Bunker 2010, Décary-Hétu and Morselli 2011).

Criminals have also used banners or signs to communicate publicly. In 2002, a banner at a Sicily football game sent a warning to the national government regarding a new law to impose stronger punishments against mafia members (Carbray 2002). In 2013 in McAllen, Texas, a cardboard sign warned the residents to pay their debt to the Zetas (Ortiz 2013). The more infamous case of banner use, of course, has been Mexico since the 2006 militarized crackdown on drug-trafficking organizations (e.g, Maihold 2012, Durán-Martínez 2017).

Banners had already been widely used in Mexico by licit actors, such as local governments and shops. Given their widespread use - probably because of relatively low cost and convenience of use - it makes sense that criminal groups would use them as well. When left next to dismembered bodies hung off at overpasses, or when posted in 
areas of public gathering, criminal groups create a general feeling of fear among society or their enemies. Atuesta (2016) offers a descriptive account of this type of messaging by criminal groups and argues that the form offers an important way to understand the development and evolution of the violence in Mexico and its meaning. Mendoza (2016) suggests that the banners blur the line between the criminal and the political. Martin (2012) identifies types of banners, from threats to public outreach. However, it is still unclear why these banners appeared in some parts of Mexico but not others.

The role of competition in explaining public communication by organized crime

This section argues competition is crucial for explaining public communication by criminal groups. We consider competition with other criminal groups, and with the state. We also discuss contestation involving the public. More specifically, the argument includes "information competition" with the news media, as well as messaging related to local drug consumption and local drug production. The underlying logic of competition applies to any type of public criminal communication. However, we specify how these factors should be associated with messages to specific audiences. We focus on three audiences: other criminals, authorities, and the general public.

Direct interorganizational competition is likely to play a role in communication by criminal groups. These groups vie for market space and could use public messages to identify their territory and warn other criminal competitors about their power (Martin 2012). Multiple criminal groups present in an area has been shown to be important for explaining violence (Durán-Martínez 2015a, Osorio 2015, Ríos 2013), and as these groups attack each other, so it is likely to affect other outcomes such as public 
communication as well. Indeed, Durán-Martínez (2015a) finds that intergroup competition is associated with more visible types of criminal violence. Research on terrorism is also suggestive of this notion, as it shows that groups are more likely to claim their attacks when there are multiple terrorist groups present in the same area (Hoffman 2010, Abrahms and Conrad 2017).

In the context of intergroup competition, criminal organizations face incentives to get the public and authorities on their side. The public can provide valuable information to a criminal organization, and messages directed to the police could attribute guilt for certain criminal actions to other criminal organizations. Information collected from the public can help law enforcement (e.g., Waldoff and Weiss 2010), and enforcement operations conducted against certain criminal groups could weaken them with respect to their enemies (Carpenter 2010, Trejo and Ley 2018). As criminal organizations compete for public loyalty, it makes sense that they would threaten the public or the police (Atuesta 2016), or try to convince them that other groups or the state are the enemy (Castillo and Cruz 2014, Martin 2012). Intergroup competition should lead to public messaging, whether the messages are targeted at rival groups, authorities, or the public. H1: Interorganizational competition leads to a higher likelihood of criminal group public communication.

Competition with the government is also likely to lead to public communication. Criminal groups are engaged in long-term contestation with the state, as both sides try to out-smart the other (Kenney 2007). State enforcement can upset preexisting equilibria, and often leads to more criminal violence (Dell 2015, Lessing 2017, Osorio 2015, Ríos 2013; Ríos 2015). It is likely that enforcement operations affect public communication as 
well. ${ }^{6}$ Emerging criminal organizations can use public communication to change the size, nature or objective of enforcement operations (Campbell 2012, Durán-Martínez 2015a, Atuesta 2017). Narco-messages are used to intimidate authorities, to report that another organization is doing something they consider immoral or illegal (Barboza 2008), to accuse them of receiving bribes and not delivering protection (Roque Madriz 2010), or complain about the effects of enforcement operations on the stability of the region (Belmonte Torres 2009).

The relationship between authorities and organized crime is different depending on the level of government. Enforcement activities against organized crime are often conducted by the military or federal authorities that are not only more professional, but more prone to be influenced by national-level political considerations (Sabet 2012). State and local polices might take more a lax approach towards enforcement. Clientelism, personalistic leadership, and appointments of local police chiefs based on camarilla loyalties, instead of technical expertise and professional experience, are common practice (Sabet 2012). Municipal police forces have long been an obstacle in fighting organized crime because of their relationships with criminal groups (Sabet 2010, Solar 2015). Sometimes when local police arrest members of an organized crime group, it is at the behest of the group's rivals.

Overall, the type and effectiveness of enforcement varies depending on the level of government, but there have been substantial enforcement operations aimed at criminal organizations. In the presence of such crackdowns, public communication by criminal groups seems like a likely response. This suggests the following hypothesis: 
H2: Government enforcement leads to a higher likelihood of criminal group public communication.

In addition to trying to communicate with other criminal groups and the state, criminal organizations also try to address the public more broadly. One relevant aspect of public communication involves efforts to control information from the mass media (Ríos and Ferguson 2019, Ríos and Rivera 2018). In certain locations there is fierce competition over the control of information (Holland and Rios 2017). The role of information is instrumental to the reputation building of criminal organizations and helps them achieve massive dissemination of their message if media coverage exists (Campbell 2012, Durán-Martínez 2015a). When information is especially salient, criminal organizations want their side to be represented.

How do we recognize information competition? Attacks on the media are an indicator of such competition since both media and criminal organizations seek the public's attention. Throughout the world, the assassination of journalists is unfortunately common (Gohdes and Carey 2017, Holland and Ríos 2017), and perpetrators include states, insurgents, and criminal groups. In these situations, information provision to the public is disputed. When this happens, it is likely also that violent actors such as criminal groups will be engaging in their own communication with the public. This is not necessarily to suggest that one phenomenon causes the other, but that both stem from competition over information.

In the context of the Mexican drug war, information competition has manifested itself in a number of ways. Criminal groups have attacked journalists to get them to reduce or their coverage of crime, and to strategically get the journalists to publish more 
favorable coverage. ${ }^{7}$ Some narco-messages contain direct threats to journalists, alluding to their formal or informal allegiances to rival criminal groups (El Siglo de Durango 2010). ${ }^{8}$ Even when messages are not directed at journalists, the notion of information competition suggests criminal groups are trying to shape public discussions about them. For instance, trying to convince the public that other groups or the state are the enemy (Castillo and Cruz 2014, Martin 2012).

It is important to mention that self-censorship, political intimidation, attacks by local private powers, and other practices have created an environment of media restrictions in Mexico before contemporary criminal elements emerged. Journalists have been assassinated, almost always without sanction, since at least the late XIX century, with both public and private interests behind these crimes (Moncada 2012). Other forms of non-violent coercion and co-optation had also long played a role in limiting free press and the democratic spread of information (Lawson 2002). Poor salaries and contracts, for example, hamper efficient reporting and proper research journalism (Rodriguez Luna 2017). Given this history, it seems that criminal groups might be adapting to it in their own way, sometimes choosing to produce their own publicity in a crowded and especially dangerous information environment. In other words, when information is more salient, criminal groups should use do-it-your-self publishing.

H3: Information competition leads to a higher likelihood of criminal group public communication.

We also consider two ways local markets might be valuable and, as a result, encourage criminal groups to publicly communicate: local consumption, and local drug production. While criminal organizations do not always deal exclusively in drugs - they 
can engage in any illegal product or service provision - the drug market is the most profitable, and probably most commonly discussed, lucrative activity for criminal organizations (UNODC 2011). Regarding the local market, when a local community includes a substantial number of illegal drug consumers, this suggests a particular kind of relationship between organized crime and the public.

In Mexico, since the early 2000s, instead of simply transporting products through the area, criminal organizations seem to increasingly depend on the locals as customers and as a result are especially likely to share information with them. Communications could include threats to authorities or other criminal groups, and warnings about law enforcement (Martin 2012). Given the valuable local market, groups also face heightened incentives to threaten competing organizations and the government. ${ }^{9}$ However, independently of interorganizational competition, the relationship between traffickers and the general public is likely to result in a greater likelihood of public communication. Groups might want to advertise to potential consumers, warn potential customers to not buy from the competition, and recruit lower-level dealers. Overall, this suggests the following hypothesis:

H4: Local market competition leads to a higher likelihood of criminal group public communication.

Beyond a local market regarding consumption, certain areas are better than others for production. A territory with homegrown drugs, such as marijuana and opium poppies, is of special value to criminal organizations (Dube et al 2016). Mexico has always been a leading supplier of marijuana, but started to gain importance due to its 
supply of heroin in recent decades (USDS 2011). This changed the dynamics of criminal group operations. Criminals were not only interested in controlling drug trafficking routes, but also in controlling rural areas engaged in drug crop cultivation (Escalante 2009). Given the value of these territories, groups face heightened incentives to threaten competing organizations through public communication. They are also likely to threaten authorities who might interfere with production. Perhaps more importantly, the criminal organizations communicate with land owners and farm workers. Regardless of the specific audience, local drug production represents an area of great interest to criminal organizations, and one that should inspire public communication by these groups. H5: Local drug production leads to a higher likelihood of criminal group public communication.

\section{Aiming at specific audiences: Other criminals, the state, and the public}

While the hypotheses above are about the likelihood of public communication in general, here we briefly specify that certain types of behavior should be associated with communication aimed at particular audiences. We focus on the three possible audiences mentioned previously: other criminals, the state, and the public. This should help to clarify causal mechanisms, and potentially add some validity to the primary results. First, while there are reasons to expect that intergroup competition should lead to communication with all three audiences, it seems likely that groups confronting each other should also publicly communicate with each other. 
H6: Criminal group competition leads to a higher likelihood of criminal group public communication especially when the intended audience is other criminal groups, as opposed to other audiences.

Second, state enforcement might spur criminals to communicate to other audiences, but it seems especially likely to encourage criminals to send messages to the state. Criminal groups demand that the state back off, blame their peers, and threaten politicians. This type of response seems realistic.

H7: Government enforcement leads to a higher likelihood of criminal group public communication where the intended audience is the state, as opposed to other audiences.

Finally, attacks on the media, a local drug market, and local drug production should all be associated with communication aimed at the public. Attacks on the media indicate an interest in control over information distributed to the public. In these situations, criminal groups are trying to reach out to the public, so it would make sense that they would also directly address the public in their own communications. Regarding local drug consumption, the presence of such consumption suggests many members of the public are potential consumers. When there is local production, many farmers are suppliers in the production chain, and their neighbors are probably aware of this. In this context, criminal groups might be especially likely to reach out to the public directly as issues arise, such as maintaining the loyalty of local farmers or community more broadly. 
H8: Attacks on the media, local drug consumption, and local drug production lead to a higher likelihood of criminal group public communication where intended audience is the general public, as opposed to other audiences.

\section{[Table 1 about here.]}

Table 1 summarizes the argument, indicating the important concepts behind the hypotheses primary hypotheses (H1-5), and the actors who are the intended audiences of narco-messages (H6-8).

\section{Illustrative case example}

The hypotheses are primarily evaluated using the quantitative tests in the next section. First, however, we briefly discuss an illustrative case that demonstrates the plausibility of the theorized explanation. We discuss examples from the municipality of Chilpancingo, Guerrero, which is located between Mexico City and Acapulco.

Multiple criminal groups have battled for control over Chilpancingo, and this has manifested itself in narco-messages, consistent with H1. In 2009, body parts of five men appeared in the city center, with a poster purportedly from Arturo Beltran Leyva, a powerful criminal leader. The sign mockingly called rival groups to send "more qualified people," implying that they tried to attack his group but failed (Ramos 2009). The Beltran Leyva group had been fighting the Sinaloa Cartel and La Familia Michoacana in the area. The communication to rival groups suggests support for H6.

When Mexican Marines killed Beltran Leyva several months later in a neighboring state, a narco-message at a nearby kindergarten warned authorities of a counterattack (El Universal 2009b). This response to enforcement is consistent with $\mathrm{H} 2$, 
and the government audience is consistent with H7. Criminal groups also deployed narco-messages in Chilpancingo to respond to authorities. For example, as security forces swept the area, narco-mantas addressed President Calderón, asking him to "respect families" and not involve innocent relatives of criminal group members (Reforma 2009). Competition over information is apparently an issue in Chilpancingo. In 2010, a local crime reporter was found dead in a ditch with five bullet wounds in his body (El Universal 2010). ${ }^{10}$ As noted previously, criminal groups often attack journalists for reporting news in a way that is divergent from what the criminals want. A desire to shape public perceptions is also likely to help explain the regular occurrence of narco-messages, as $\mathrm{H} 3$ suggests. Related to this, criminal organizations have close relationships with a substantial number of inhabitants of Chilpancingo due to local drug consumption and production (e.g., BBC 2013, Galarce Sosa 2012). Ties to the public contribute to the idea of information competition, as groups in Chilpancingo seem to use narco-messages to convince the community that they are on their side. This would be consistent with H4, $\mathrm{H} 5$, and $\mathrm{H} 8$.

For example, in 2009 a sign - purportedly signed by Beltran Leyva accompanying bags of human body parts criticized the dead as kidnappers and informed the public to not be alarmed by the deaths (El Universal 2009a). In 2016, a similar message told the pubic that they were not targets, informing them not to be worried by violence (El Sur 2016). In 2018, a narco-message from Cartel del Sur announced, “Citizens of Chilpancingo know that we don’t kidnap or extort” (Uno Más Uno 2018). Appealing to the public seems more likely when criminal groups depend on the local population and therefore feel a need to keep it on their side. The coexistence of journalist 
targeting, drug consumption, drug production, and narco-messages to the general public in Chilpancingo suggests the logic outlined for $\mathrm{H} 8$.

This brief snapshot provides some evidence supporting the theorized relationships, at least in this municipality. We have found similar patterns in other municipalities, such as Ecatepec, Estado de México; Zitácuaro, Michoacán; and Tecate, Baja California. The next section seeks to understand if there are relationships between hypothesized factors and narco-messages throughout the country.

\section{Data and analysis}

Our quantitative analyses use an original database of about 1,800 narco-messages found in Mexico during 2007-2010. In general, narco-messages are texts left by criminal organizations in a public place to communicate with other criminal groups, the public, or authorities. Some examples of reasons why these signs appear include to clarify why they assassinated someone, to intimidate other potential victims, or to identify themselves or their victims. The text can be professionally printed on vinyl banners, hand-written on cardboard signs, or scrawled on bedsheets. Narco-messages are a disturbing innovation that stretches the boundaries of traditional graffiti and that, mimicking the campaign language of Mexican political parties with a tone that can be oddly formal (Salopek 2011), function to communicate with citizens around the area, or give instructions to the police, journalists or local public officials. The most common topics of narco-messages are displays of territorial control, encouragement to cooperate with the sender, corruption accusations, attempts to enforce internal drug codes, or to explain their activities (Martin 2012). ${ }^{11}$ 
Our data set is unique because it not only contains information of the municipality and date of each of the 1,800 narco-messages, but also records the complete message and the intended recipient of the message when available. To gather this information, we performed massive amounts of queries at online search engines using Spanish translations of narco-message(s) as our keywords. In the same way that Coscia and Rios (2012) searched for criminal activity, we relied on Google as our main search engine, but we also gathered a team of researchers to read, filter and classify all the results. We used information from local newspapers, amateur blogs and forums (e.g. "El Blog del Narco"). One complication we faced was to make sure that each narco-banner was independent, and not just a replica covered by different media sources. When a message contained the same text, was displayed in the same municipality, and around the same date, we assumed it could be duplicated coverage.

To test hypotheses 6-8, we disaggregate the dependent variable depending on whether the banners targeted other criminal groups, the government, or the public. Unfortunately, for many banners it was unclear who the intended audience was. The rest were coded as directed to a group, government, or public. A single message can be classified in more than one category. The most common category is criminal group with 983 cases. The same number of messages are coded for public or government audiences 258 each.

The unit of analysis of the study is municipality-year, and models examine the nearly 2,500 Mexican municipalities in four years: 2007-2010. These have been some of the most violent years of the so-called "drug war." Additionally, and importantly from a research design perspective, many media outlets stopped reporting about narco-messages 
in 2011 at the government's encouragement (Martínez 2011). As a result, counts of narco-messages starting in 2011 could under-count the number of messages, and a timeseries study with data before and after 2011 is potentially problematic. The dependent variable is Narco-message, a dichotomous variable coded "1" if a narco-message was reported in the municipality that year. We use a dichotomous variable, instead of a count, because we are interested in the presence or absence of narco-messages more than a change in their number. Additionally, the vast majority of observations never have a narco-message. The important variation seems to be between 0 and 1. (Results are similar if a count model is used.) Map 1 shows narco-messages appeared throughout Mexico.

\section{[Map 1 about here.]}

To measure interorganizational competition, for the first hypothesis, we use Criminal organizations, a count of the number of criminal groups reported to be operating in the municipality in the year. For this variable, we use the Cosia and Rios (2012) data, which employs a text-analysis algorithm to extract web content about recorded criminal activities (Coscia and Rios 2012). This data set has been widely used (Osorio 2015, Gonzalez 2015, Dube et al 2016). For the hypothesis about government enforcement, we use data from Osorio (2015) on violent confrontations by authorities to create the variable Government enforcement. The municipality-year is coded "1" if authorities attacked, killed, or wounded presumed members of organized crime. For the third hypothesis, about information competition and attacks on the media, we include Journalist killed, a variable coded "1" if a journalist had been killed in the municipality that year. We use data collected by the Committee to Protect Journalists (CPJ). There are alternative sources, however, we work with CPJ data because it uses a strict coding 
mechanism. ${ }^{12}$ Moreover, it is the largest available time series. The data include 27 cases of journalists assassinated in 13 states. We identified the exact municipality by examining the details of the cases covered by the media.

Drug consumption, to test the fourth hypothesis, is a dichotomous measure coded "1" in municipality-years where at least one person has been hospitalized for a reason related to illegal drugs (SSA 2008-2011). A similar exercise was done by [Author Year] using data of mortality certificates and hospitalization records. Our new data is innovative because it is not limited to patients that occupied a bed in the hospitalization area, but all cases of medical emergencies, that is, all those cases when an individual entered an emergency room. We collected and systematized data from medical emergencies datasets to identify the extent to which drugs are commonly consumed by counting cases of urgent medical attention caused by the consumption of illegal drugs. ${ }^{13}$ This required us to perform the substantial task of reviewing millions of medical and legal records for every case of drug-consumption-related medical urgency recorded from 2007 to 2010.

The sources contain the registry of the codes of medical issues presented by the individuals according to the international classification of diseases. The location associated with the hospitalization is the municipality where the medical event happened, not where it was registered. This location is reported by the patient herself, or in case of death, it is the place of residence of the victim. Drug consumption rates in Mexico are quite low. Consistent with this, very few municipalities have medical emergencies for drug-related reasons. For the fifth hypothesis, we use Drug production, a 0-3 ordinal 
variable from Osorio (2015) that indicates the degree of presence of local drug cultivation.

Models include a number of control variables to take into consideration alternate explanations for the appearance of narco-messages. Models include the three categories of "drug-related homicides" according to the Mexican government: confrontations, executions and aggressions (SNSP 2007-2011). Among drug-related homicides, "confrontations" are homicides caused by confrontations between two rival criminal organizations. "Aggressions" are criminal group attacks against authorities. "Executions" are those in which the victim was visibly targeted, rather than killed as part of a shootout. Variables use rates per 100,000 inhabitants. These measures are not highly correlated. In general, there do not seem to be multicollinearity issues in models, as indicated by pairwise correlation tests and variance inflation factors.

Regarding political dynamics, we include a dummy variable called PAN municipal government coded "1" for municipalities ruled by the National Action Party. These municipalities had more violence than others (Dell 2015). Federal coordination is a dichotomous variable coded " 1 " if the municipality and state are ruled by the same political party. We expect this to be negatively related to narco-messages because previous work shows that coordination across levels of government can be crucial to maintaining the status quo regarding organized crime (Snyder and Duran-Martínez 2009, Trejo and Ley 2018). We also include a dummy called Government turnover, coded "1" in the first year that a new municipal government had taken office. Some studies have shown that government alternation breaks relationships between the state and organized crime, leading to strife (Trejo and Ley 2018). 
During the years of this study, the Mexican government launched major military operations to battle organized crime - but only in certain parts of the country. To take this into consideration, we include Military presence, which counts army deaths in each stateyear. This is an imperfect measure, but we do not have precise data on armed forces deployments over time. Military presence is not highly correlated (<.20) with Government enforcement, perhaps because multiple government actors confront organized crime. Data come from the Drug Policy Program (PPD) at the Center for Research and Teaching in Economics (CIDE).

Regarding geographic and demographic factors, we include U.S. border, coded "1" for municipalities in states that border the United States. Economic inequality is the standard Gini coefficient measure of income inequality in each municipality (CONEVAL 2010). Some studies find inequality related to crime (Enamorado et al. 2016, Phillips 2017), so it could also help explain messaging. Economic development is an index of economic vulnerability that measures basic development indicators (CONAPO 2011). Population is a natural logarithm of the municipality population (CONAPO 2014). Models include year dummy variables because narco-messages might be more common in some years than other, but these variables are not shown for space reasons.

The model is a rare events logistic regression (King and Zeng 2001) because around 95 percent of the observations are zeroes. However, results are robust if a regular logit is used. Standard errors are clustered by municipality. Results are robust to other approaches, some of which are discussed below.

Results 


\section{[Table 2 about here.]}

In Table 2, Model 1 is the primary model, with the dependent variable of narcomessage regardless of intended audience. Criminal groups is statistically significant and positively signed. This suggests support for the first hypothesis. Regarding substantive significance (see Figure 1), odds ratios suggest that for each additional criminal group in a municipality, the municipality is almost 3 times as likely to have a narco-message. Government enforcement is statistically insignificant. This is unexpected and suggests government violence against criminal groups is not related to public communication by these groups. However, results below suggest that depends on the audience of the communication. Journalist killed is statistically significant and positively signed. This suggests support for the third hypothesis, although the statistical significance is not as strong as it is for some other variables. A municipality with a journalist killing is about twice as likely as one without one to have a narco-message. Both Drug consumption and Drug production are statistically significant and positively signed, as expected. Local drug business is related to public communication by criminal groups, suggesting support for hypotheses 4 and 5 . The presence of drug consumption or drug production indicates a municipality is about 1.5 times as likely as another municipality to have a narco-message.

\section{[Figure 1 about here.]}

Models 2-4 use the disaggregated versions of the dependent variable, depending on the intended audience of the banners. Substantive effects are shown in Figure 2. In Model 2, the dependent variable is narco-messages aimed at criminal organizations. In this model, Criminal organizations has a larger coefficient than it did in Model 1, or indeed any of the models, lending some support to the idea that interorganizational 
violence is especially associated with communication with other groups, Hypothesis 6. Model 3 uses the dependent variable of banners targeted at authorities. Only in this model is Government enforcement statistically significant and associated with the dependent variable. This supports hypothesis 7. Model 4's dependent variable is narco-messages intended for the public. As expected, the coefficient on Journalist killed is highly statistically significant and much larger in this model, consistent with Hypothesis 7. Figure 2 demonstrates that a municipality where a journalist was killed is almost four times more likely to have a narco-message aimed at the public. However, the results for Drug consumption and Drug production are similar to or weaker than their results in Model 1, suggesting local drug business dynamics are not especially associated with communication targeting the general public as expected. There is mixed support for Hypothesis 7, but the difference in results regarding Journalist killed is remarkable.

\section{[Figure 2 about here.]}

Many of the control variables return expected results. Regarding violence measures, none of the homicide measures are consistently associated with narcomessages. One homicide measure, Aggressions is statistically significant in two models, correlated with narco-messages in general and those targeting authorities. This makes sense because the "aggressions" category are those involving attacks against authorities.

Regarding political variables, PAN municipality is only statistically significant in the first model, and negatively signed. This is surprising because other work finds areas ruled by the PAN party were especially violent (Dell 2015). This is suggestive that violence and the narco-messages are two distinct phenomena. Contrasting with this, in most models there is a statistically significant and negative sign on the coefficients for 
Federal coordination, as expected. However, Government turnover is also statistically significant and negatively signed in two models, while alternation is usually associated with increased violence. Military presence is statistically significant and positively signed in all models, suggesting areas with military deployments and fatalities are more likely to see narco-messages. Together these results suggest that some of the determinants of violence are also associated with narco-messages, while others are not.

The coefficient on US border is statistically significant but negatively signed in all models. This suggests that municipalities in states near the U.S. border are less likely than other municipalities to have a narco-message. This is surprising, but it could be because many areas bordering the US are not official ports of entry, and therefore less disputed by criminal groups. While narco-messages occurred throughout the country, for various reasons there might have been a greater concentration of them far from the U.S. border, in the southern part of the country. Alternately, perhaps the stakes at the border are so high that groups simply engage directly in violence instead of communicating threats or other messages. Economic inequality is statistically significant and positively signed in most models, as expected. Economic development is always negatively signed and statistically significant, as expected. The coefficient on Population is statistically significant and positively signed in most models, suggesting more populous municipalities are more likely to have public criminal communication.

These results, particularly of Model 1, are robust to many changes not shown here for space reasons. ${ }^{14}$ Most results are consistent with the following changes: no control variables, only violent municipalities, municipality random effects instead of clustered standard errors, or a traditional logit instead of rare events logit. If count models (e.g., 
zero-inflated negative binomials) are used with a count of narco-messages, results are robust. In other words, the factors associated with an increased likelihood of narcomessages are also associated with additional narco-messages in the same area.

\section{Conclusion}

Why do criminal organizations sometimes publicly communicate with the government, their rivals, and the public? Criminal groups around the world exhibit this behavior, which in some ways is like tactics of insurgent or terrorist organizations (Phillips 2018). However, the precise motivations behind public criminal communication have been unclear. This paper outlined a theory of competition and tested it on an important case, Mexico in the early years of its "drug war." Consistent with the theory, results suggested that narco-messages were especially likely to appear in municipalities with multiple criminal groups, where the state had violently confronted groups, where competition over information had led to the murder of journalists, and where there was local drug consumption or production. Other factors robustly associated with narcomessages were military deployments, economic inequality and poverty. Interestingly, some variables often related to violence, such as PAN municipal governance, show no consistent relationship with narco-messages. We found government turnover, associated with criminal violence in other studies, negatively related to the messages.

These findings are important for several reasons. First, they shed light on the public and informational aspects of organized crime. While criminal groups' motives are ultimately financial, they nonetheless behave in some ways like political actors, reaching out to governments and regular citizens (Campbell and Hansen 2013), and the violence 
has many political implications (e.g., Ley 2017). The relationship between the killing of journalists and the appearance of narco-messages suggests public information provision can be a crucial element of organized crime. Second, some findings suggest that explanations of organized crime violence are distinct from explanations of organized crime public communication. Additionally, only certain violence measures were related to narco-messages. Criminal communication does not only appear where criminal violence occurs, but in a broad range of places and for distinct reasons.

The findings suggest additional steps for future research. Are the determinants of public communication by criminal organizations similar in other cases, such as graffiti or social media? Regarding more fine-grained analysis of the narco-messages, what does their content tell us about the nature of violence in Mexico? Some descriptive analysis of the texts of narco-messages reports interesting findings (Martin 2012, Atuesta 2016), but more work remains to be done. What can we learn from patterns in the contents of narcomessages? And are the patterns we find in this study consistent in more recent years?

Finally, some work could be done to try to understand downstream effects after criminal public communication appears. Does criminal communication affect subsequent crime, or in other ways warn us about likely future behavior? 


\section{Works cited}

Abrahms, Max, and Justin Conrad. "The Strategic Logic of Credit Claiming: A New Theory for Anonymous Terrorist Attacks." Security Studies 26.2 (2017): 279-304.

Atuesta, Laura H. "Narcomessages as a way to analyse the evolution of organised crime in Mexico." Global Crime (2016): 1-22.

Atuesta, Laura H., and Yocelyn Samantha Pérez-Dávila. "Fragmentation and cooperation: the evolution of organized crime in Mexico." Trends in Organized Crime 21.3 (2018): 235-261.

BBC Mundo. La proliferacion de los "narcotaxis” en Mexico. Aug. 15, 2013.

Barboza, Roberto. 2008. "Aparecen narcomantas en Tabasco" El Universal, Estados. August 29th, 2008.

Belmonte Torres, Juan José. 2009. "Ejecutan a policía en Zihuatanejo" Noticias Acapulco. March 3rd, 2009.

Brown, Joseph M. 2017. "Notes to the Underground: Credit Claiming and Organizing in the Earth Liberation Front." Terrorism and Political Violence forthcoming. Calderón, Gabriela, Gustavo Robles, Alberto Díaz-Cayeros, and Beatriz Magaloni. 2015. "The beheading of criminal organizations and the dynamics of violence in Mexico.” Journal of Conflict Resolution 59 (8): 1455-1485.

Campbell, Howard. "Narco-Propaganda in the Mexican "Drug War" An Anthropological Perspective." Latin American Perspectives 41.2 (2014): 60-77.

Campbell, Howard, and Tobin Hansen. "Is Narco-Violence in Mexico Terrorism?" Bulletin of Latin American Research 33.2 (2014): 158-173. 
Carbray, Paul. 2002. "Handkerchiefs on Display as Barcelona Fans Protest: South American Teams are Biggest Losers as World Cup Final Spots are Adjusted." The Gazette (Montreal). Dec. 23, 2002.

Carpenter, Ami C. "Beyond drug wars: transforming factional conflict in Mexico." Conflict Resolution Quarterly 27.4 (2010): 401-421.

Castillo, Melitón Guevara, and Cruz Alberto Martínez Cruz. "Las narcomantas: vía para producir noticias en un clima de violencia." Book chapter.

Chermak, Steven, and Nicole M. Chapman. "Predicting crime story salience: A replication." Journal of Criminal Justice 35.4 (2007): 351-363.

Coggins, Bridget L. 2015. "Rebel Diplomacy: Theorizing Violent Non-State Actors' Strategic Use of Talk." In Rebel Governance in Civil War (Ana Arjona, Nelson Kasfir, Zachariah Mampilly, eds.) 98-118.

Coleman, Joseph. “Cartel: 'We don't plan Bush assassination'.” UPI, 29 Jan. 1990,

Coscia, Michele, and Viridiana Rios. "Knowing where and how criminal organizations operate using web content." Proceedings of the 21st ACM international conference on Information and knowledge management. ACM, 2012.

CONAPO Índice absoluto de marginación 1990-2000. Datos Abiertos, CONAPO, 2011. CONAPO Proyecciones de la Población 2010-2050. Datos Abiertos, CONAPO, 2014.

CONEVAL. Estadísticas de desigualdad por municipio, 2010. Índice de Cohesión Social. CONEVAL, 2010.

Cowell, Alan. 1992. "Big Palermo Rally Assails Mafia Grip.” The New York Times. June 27. 
Décary-Hétu, David, and Carlo Morselli. "Gang presence in social network sites." International journal of cyber criminology 5.2 (2011): 876.

Dell, Melissa. "Trafficking networks and the Mexican drug war." The American Economic Review 105.6 (2015): 1738-1779.

Durán-Martínez, Angélica. "To kill and tell? State power, criminal competition, and drug violence." Journal of Conflict Resolution 59, no. 8 (2015): 1377-1402.

Durán-Martínez, Angélica. "Drugs Around the Corner: Domestic Drug Markets and Violence in Colombia and Mexico." Latin American Politics and Society 57.3 (2015) 122-146.

Durán-Martínez, Angélica. (2017) "Silent Traffickers or Brutal Criminals: How State Power Shapes Criminal's Incentives to Expose Violence" in Menjívar, C., \& Davis, D. E. (2017) in Violence and Crime in Latin America: Representations and Politics University of Oklahoma Press.

Dube, Oeindrila, Omar García-Ponce, and Kevin Thom. "From maize to haze: Agricultural shocks and the growth of the mexican drug sector." Journal of the European Economic Association 14.5 (2016): 1181-1224.

El Sur. Dejan una narcomanta en el centro de Chilpancingo. July 30, 2016.

El Universal. Violencia-Guerrero. Dec. 16, 2009.

El Universal. Colocan narcomanta en Morelos. Dec. 22, 2009.

El Universal. El Peligro de Informar. 2010. http://interactivo.eluniversal.com.mx/periodistas-asesinados/anios/2010.html 
Enamorado, T., L. F. Loopez-Calva, C. Rodriguez-Castellan, and H. Winkler (2016). Income inequality and violent crime: Evidence from Mexico's Drug War. Journal of Development Economics 120, 128-143.

Escalante, Fernando. 2009. "Territorios violentos". Nexos. December 1.

Ferrarin, Elena. 2011. March Honors Gang-Shooting Victim in Elgin." Chicago Daily Herald. Oct. 16.

Finckenauer, James O. "Problems of definition: What is organized crime?." Trends in organized crime 8.3 (2005): 63-83.

Fink, Katherine, and Michael Schudson. "The rise of contextual journalism, 1950s2000s." Journalism 15.1 (2014): 3-20.

Flores Contreras, Ezequiel. Junto a ejecutado dejan narcomensaje contra portal noticioso y funcionarios de Astudillo. Proceso. June 5, 2018.

Galarce Sosa, Karla. Guerrero, lugar 18 nacional en consume de drogas, segun funcionario estatal. El Sur. June 28, 2012.

Gambetta, Diego. 2009. Codes of the Underworld: How Criminals Communicate. Princeton, NJ: Princeton University Press.

Gohdes, Anita R., and Sabine C. Carey. "Canaries in a coal-mine? What the killings of journalists tell us about future repression." Journal of Peace Research 54.2 (2017): 157-174.

Guevara, America Y. "Propaganda in Mexico's Drug War." Journal of Strategic Security 6.5 (2013): 131. 
Hoffman, Aaron M., Crystal Shelton, and Erik Cleven. "Press freedom, publicity, and the cross-national incidence of transnational terrorism." Political Research Quarterly 66.4 (2013): 896-909.

Hoffman, Aaron M. "Voice and silence: Why groups take credit for acts of terror." Journal of Peace Research 47, no. 5 (2010): 615-626.

Holland, Bradley E., and Viridiana Ríos. "Informally Governing Information: How Criminal Rivalry Leads to Violence against the Press in Mexico." Journal of Conflict Resolution 61.5 (2017): 1095-1119.

Huang, Reyko. 2016. "Rebel Diplomacy in Civil War." International Security 40 (4): 89126.

INEGI. Estadísticas vitales 1990-2016. data retrieved from Instituto Nacional de Geografía y Estadística, http://www.inegi.org.mx/sistemas/olap/proyectos/bd/ continuas/mortalidad/defuncioneshom.asp?s=est.

Kalyvas, Stathis N. The logic of violence in civil war. Cambridge University Press, 2006.

Kearns, Erin M., Brendan Conlon, and Joseph K. Young. "Lying about terrorism." Studies in Conflict \& Terrorism 37, no. 5 (2014): 422-439.

Kenney, Michael. 2008. From Pablo to Osama: Trafficking and Terrorist Networks, Government Bureaucracies, and Competitive Adaptation. College Station: Penn State University Press.

King, Gary, and Langche Zeng. "Logistic regression in rare events data." Political analysis 9.2 (2001): 137-163.

Lantz, Andrew “The performativity of violence: Abducting agency in Mexico’s drug war.” Journal of Latin American Cultural Studies 25.1 (2016):253-269. 
Lawson, Joseph Chappell H. Building the fourth estate: Democratization and the rise of a free press in Mexico. Univ of California Press, 2002.

Lessing, Benjamin. 2017. Making Peace in Drug Wars: Crackdowns and Cartels in Latin America. Cambridge University Press.

Ley, Sandra. 2017. Electoral accountability in the midst of criminal violence: Evidence from Mexico. Latin American Politics and Society, 59 (1), 3-27.

Maihold, Günter "Las comunicaciones criminales. El caso de las narcomantas." Sergio Aguayo, \& Raul Benitez, Atlas de la seguridad y la defensa en México (2012).

Martin, Carlos. "Categorization of Narcomessages in Mexico: An Appraisal of the Attempts to Influence Public Perception and Policy Actions." Studies in Conflict \& Terrorism 35.1 (2012): 76-93.

Martínez, Fabiola. 2011. “Medios de comunicación firmarán pacto sobre cobertura de violencia del narco. La Jornada. March 24.

Mendoza Rockwell, Natalia. "Narco-mantas o el confín de lo criminal." Acta poética 37.2 (2016): 21-34.

Moncada, Carlos. Oficio de muerte: periodistas asesinados en el país de la impunidad. Grijalbo, 2012.

Monfries, Alice. 2012. “I'm Like a Rock Star, Says Bikie.” The Advertiser (Adelaide). January 14, 2012.

Molzahn, Cory, Viridiana Ríos, and David A. Shirk. "Drug violence in Mexico." San Diego, Trans-Border Institute, University of San Diego (2012).

National Drug Intelligence Center (NDIC). 2010. Drug Trafficking Organizations, Technical report. 
Ortiz, Ildefonso. 2013. "Family Flees After Possible Cartel Banner Left at San Juan Home." The Monitor (McAllen). May 22, 2013.

Osorio, Javier. "The contagion of drug violence: spatiotemporal dynamics of the Mexican war on drugs." Journal of Conflict Resolution 59.8 (2015): 1403-1432.

Phillips, Brian J. "How does leadership decapitation affect violence? The case of drug trafficking organizations in Mexico." The Journal of Politics 77.2 (2015): 324336.

Phillips, Brian J. "Inequality and the Emergence of Vigilante Organizations: The Case of Mexican Autodefensas." Comparative Political Studies 50.10 (2017): 1358-1389. Phillips, Brian J. "Terrorist Tactics by Criminal Organizations: The Mexican Case in Context." Perspectives on Terrorism 12.1 (2018): 46-63.

Ramos, Mar Horacio. Hallan a cinco personas descuartizadas con mensaje firmado por el Jefe de jefes. Cronica. Dec. 11, 2009.

Reforma. Reaparecen narcomantas; Piden respeto para las familias. May 12, 2009.

Ríos, Viridiana. Why did Mexico become so violent? “A self-reinforcing violent equilibrium caused by competition and enforcement”. Trends in Organized Crime, 2013, 16(2): 138-155.

Ríos Viridiana. "The role of drug-related violence and extortion in promoting Mexican migration”. Latin American Research Review, 2014, 49(3): 199-217.

Ríos, Viridiana. "How government coordination controlled organized crime. Journal of Conflict Resolution, 2015, 59(8): 1433-1454.

Ríos, Viridiana, and Chris Ferguson. "News Media Coverage of Crime and Violent Drug Crime: A Case for Cause of Catalyst?” Justice Quarterly, 2019. 
Ríos, Viridiana, and Johanan Rivera. "Media effects on brutality displays: The case of Mexico's drug war." Politics, Groups and Identities, 2018.

Rodríguez Luna, "Violence, Co-Optation and Corruption: Risks for the Exercise of Journalism and Freedom of Expression in Mexico" In Beyond the Drug War in Mexico: Human Rights, the Public Sphere and Justice, edited by Pansters, Smith, and Watt, 2017: 107-120. Routledge.

Roque Madriz, Ignacio. 2010. "Balean a jefe policiaco de Ciudad Hidalgo y a su escolta" Cronica, Nacional. April 17th, 2010.

Sabet, Daniel. "Confrontation, collusion and tolerance: the relationship between law enforcement and organized crime in Tijuana." Mexican Law Review, 2.2 (2010): 3-29.

Sabet, Daniel. Police reform in Mexico: informal politics and the challenge of institutional change. Stanford University Press, 2012.

Schmid, Alex P., and Janny de Graaf. 1982. Violence as Communication: Insurgent Terrorism and the Western News Media. Thousand Oaks, CA: SAGE.

Solar, Carlos. "Police Bribery: Is Corruption Fostering Dissatisfaction with the Political System?." Democracy and Security 11, no. 4 (2015): 373-394.

El Siglo de Durango. 2010. "Ola de violencia en La Laguna sin freno; seis decapitados" in El Siglo de Durango. May 31st, 2010.

Secretaría de Salud (SSA) "Registros de Urgencias" Dirección General de Información en Salud (2008-2011).

SNSP. Base de datos por fallecimientos por presunta rivalidad delincuencial, di ciembre de 2006 a septiembre de 2011. Data retrieved from Secretaria de Gobernación. 
Snyder, Richard, and Angelica Durán-Martínez. 2009. “'Does Illegality Breed Violence?

Drug Trafficking and State-sponsored Protection Rackets." Crime, Law, and Social Change 52 (3): 253-73.

Trejo, Guillermo, and Sandra Ley. "Why did drug cartels go to war in Mexico?

Subnational party alternation, the breakdown of criminal protection, and the onset of large-scale violence." Comparative Political Studies 51, no. 7 (2018): 900-937.

United Nations. 2004. United Nations Convention Against Transnational Organized Crime and the Protocols Thereto. Vienna: UNODC.

United States Department of State (USDS). 2011. International Narcotics Control Strategy Report. Volume I.

Uno Más Uno. July 18, 2018. Tiran Cuerpo Descuartizado de Repartidor en Chilpancingo.

Womer, Sarah, and Robert J. Bunker. "Sureños gangs and Mexican cartel use of social networking sites." Small Wars \& Insurgencies 21.1 (2010): 81-94. 


\section{Map and figures}

Map 1. The geographic distribution of narco-messages in Mexico, 2007-2010

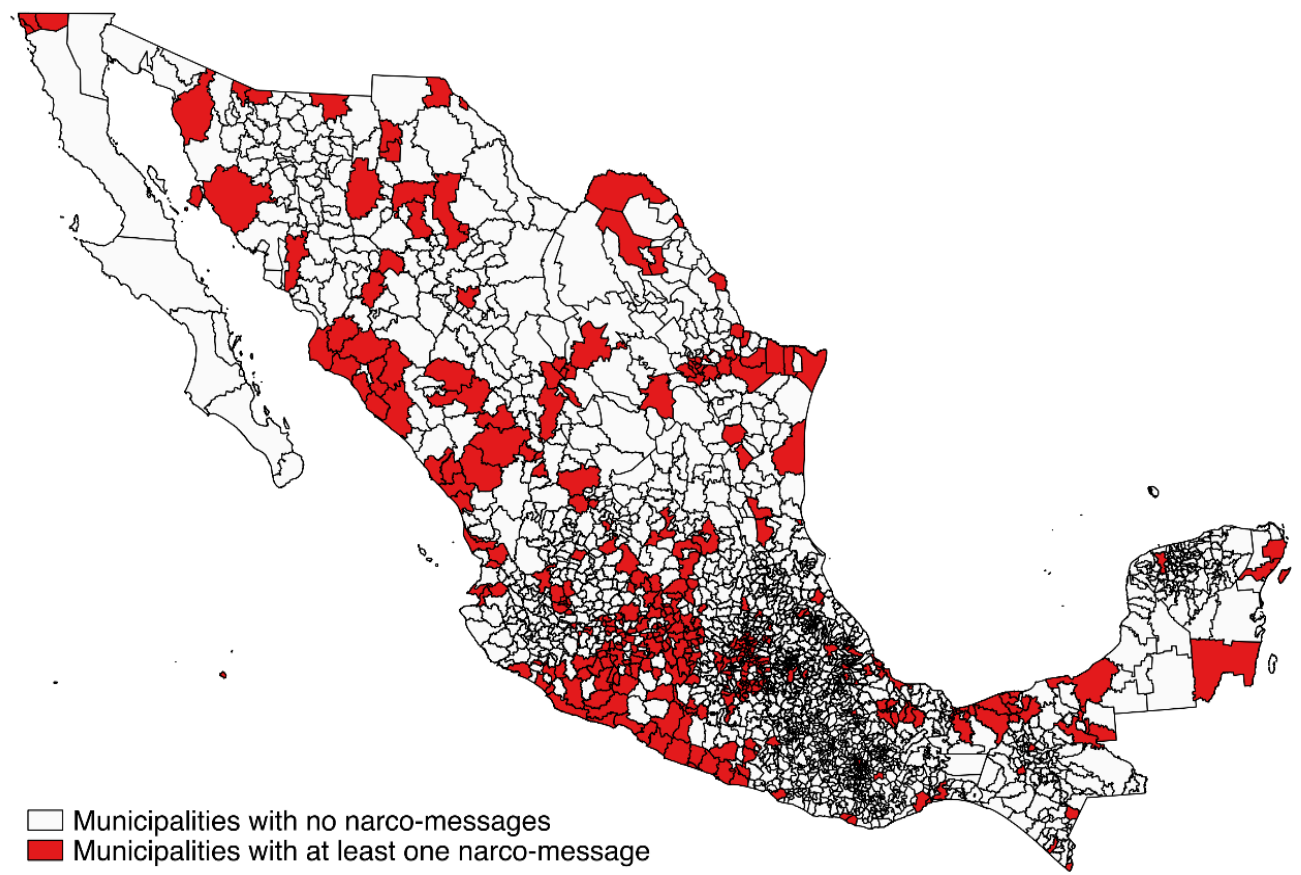

Source: Authors' data 
Figure 1. Substantive effects from Model 1: How factors relate to narco-messages

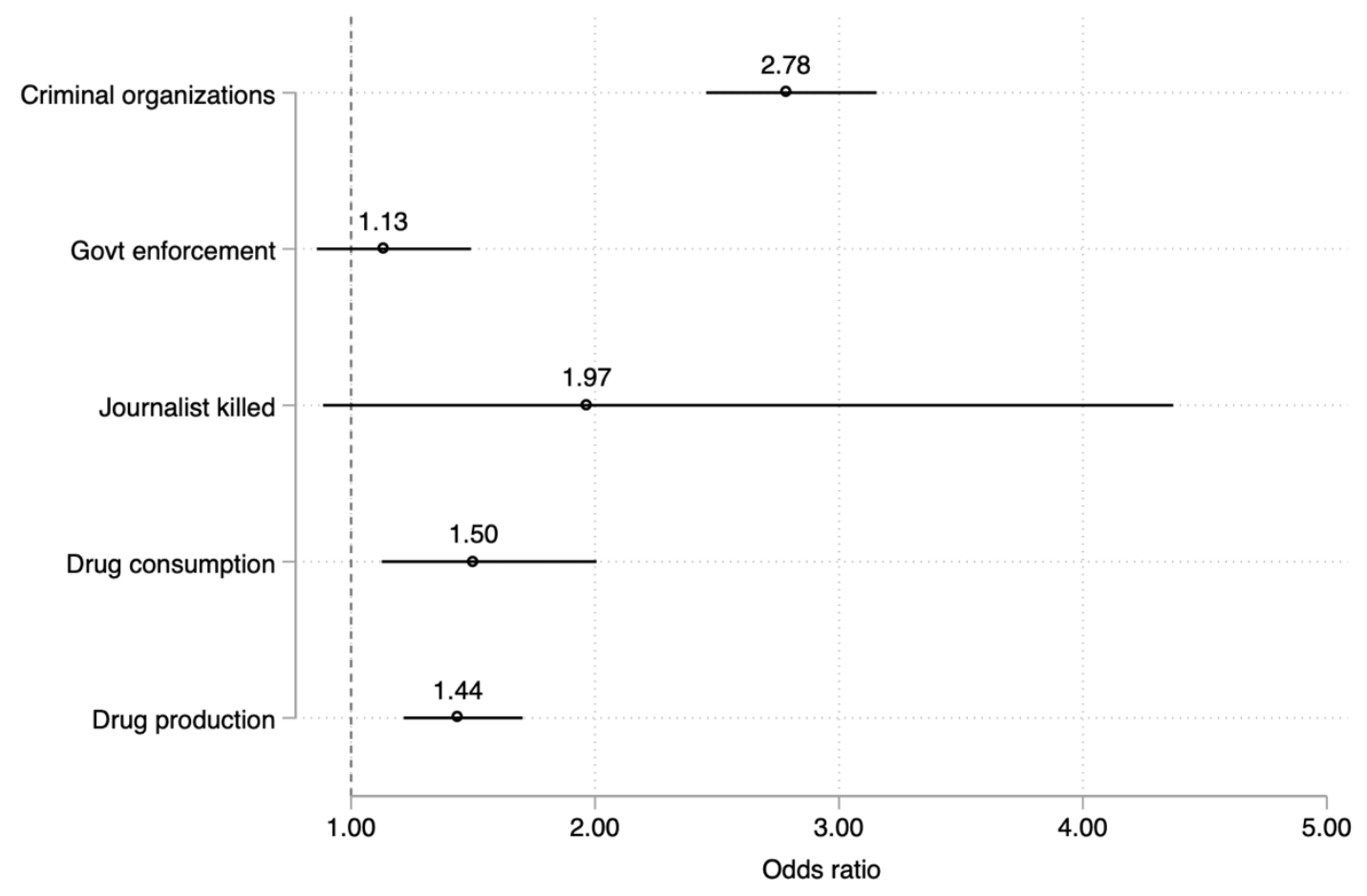

$95 \%$ confidence intervals shown. 
Figure 2. Substantive effects from Models 2-4, with different narco-message audiences

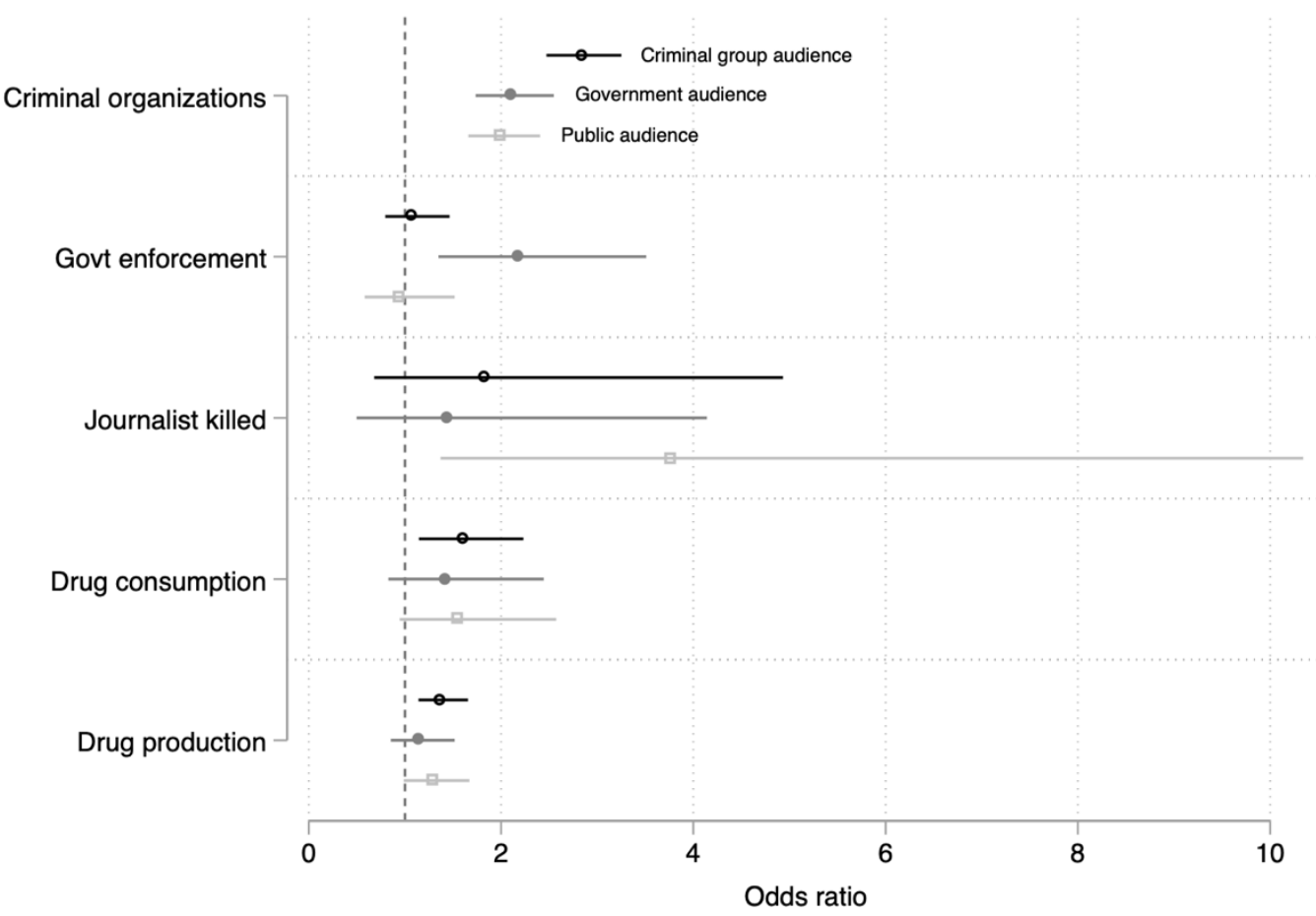

95\% confidence intervals shown. 


\section{Tables}

Table 1. Narco-messages, related factors, and intended audiences

Primary Key concept or variable Intended audience
hypotheses

\begin{tabular}{lll}
\hline H1 & Inter-group competition & Other groups (H6) \\
H2 & Government enforcement & Authorities (H7) \\
H3 & Information competition & Public (H8) \\
H4 & Drug consumption & Public (H8) \\
H5 & Drug production & Public (H8) \\
& & \\
\hline
\end{tabular}


Table 2. Rare events logistic regressions of narco-messages in Mexican municipalities

\begin{tabular}{|c|c|c|c|c|}
\hline & $\begin{array}{l}\text { Model } 1 \\
\text { Main model } \\
\text { All narco- } \\
\text { messages }\end{array}$ & $\begin{array}{l}\text { Model } 2 \\
\text { Audience: } \\
\text { Other } \\
\text { criminal } \\
\text { groups }\end{array}$ & $\begin{array}{l}\text { Model } 3 \\
\text { Audience: } \\
\text { Government }\end{array}$ & $\begin{array}{l}\text { Model } 4 \\
\text { Audience: } \\
\text { Public }\end{array}$ \\
\hline Criminal organizations & $\begin{array}{l}1.024 * * * \\
(0.064)\end{array}$ & $\begin{array}{l}1.042 * * * \\
(0.070)\end{array}$ & $\begin{array}{l}0.743 * * * \\
(0.098)\end{array}$ & $\begin{array}{l}0.692 * * * \\
(0.095)\end{array}$ \\
\hline Government enforcement & $\begin{array}{l}0.124 \\
(0.141)\end{array}$ & $\begin{array}{l}0.076 \\
(0.156)\end{array}$ & $\begin{array}{l}0.777 * * * \\
(0.244)\end{array}$ & $\begin{array}{l}-0.062 \\
(0.244)\end{array}$ \\
\hline Journalist killed & $\begin{array}{l}0.676^{*} \\
(0.407)\end{array}$ & $\begin{array}{l}0.605 \\
(0.505)\end{array}$ & $\begin{array}{l}0.361 \\
(0.541)\end{array}$ & $\begin{array}{l}1.326 * * \\
(0.516)\end{array}$ \\
\hline Drug consumption & $\begin{array}{l}0.407 * * * \\
(0.147)\end{array}$ & $\begin{array}{l}0.469 * * * \\
(0.170)\end{array}$ & $\begin{array}{l}0.352 \\
(0.276)\end{array}$ & $\begin{array}{l}0.445^{*} \\
(0.255)\end{array}$ \\
\hline Drug production & $\begin{array}{l}0.364 * * * \\
(0.086)\end{array}$ & $\begin{array}{l}0.318 * * * \\
(0.095)\end{array}$ & $\begin{array}{l}0.129 \\
(0.147)\end{array}$ & $\begin{array}{l}0.250^{*} \\
(0.134)\end{array}$ \\
\hline Execution rate & $\begin{array}{l}0.004 \\
(0.002)\end{array}$ & $\begin{array}{l}0.003 * \\
(0.002)\end{array}$ & $\begin{array}{l}0.005 * * \\
(0.002)\end{array}$ & $\begin{array}{l}0.005 * * * \\
(0.002)\end{array}$ \\
\hline Aggression rate & $\begin{array}{l}0.031 * * \\
(0.014)\end{array}$ & $\begin{array}{l}0.001 \\
(0.009)\end{array}$ & $\begin{array}{l}0.017 * * * \\
(0.006)\end{array}$ & $\begin{array}{l}0.013 \\
(0.009)\end{array}$ \\
\hline Confrontation rate & $\begin{array}{l}0.002 \\
(0.003)\end{array}$ & $\begin{array}{l}0.000 \\
(0.001)\end{array}$ & $\begin{array}{l}0.002 \\
(0.002)\end{array}$ & $\begin{array}{l}0.004 \\
(0.003)\end{array}$ \\
\hline PAN municipality & $\begin{array}{l}-0.632^{*} \\
(0.357)\end{array}$ & $\begin{array}{l}-0.611 \\
(0.395)\end{array}$ & $\begin{array}{l}-1.020 \\
(0.711)\end{array}$ & $\begin{array}{l}-0.904 \\
(0.591)\end{array}$ \\
\hline Federal coordination & $\begin{array}{l}-0.285 * * \\
(0.129)\end{array}$ & $\begin{array}{l}-0.526 * * * \\
(0.150)\end{array}$ & $\begin{array}{l}-0.361 \\
(0.227)\end{array}$ & $\begin{array}{l}-0.487 * * \\
(0.222)\end{array}$ \\
\hline Government turnover & $\begin{array}{l}-0.662 * * * \\
(0.147)\end{array}$ & $\begin{array}{l}-0.819 * * * \\
(0.169)\end{array}$ & $\begin{array}{l}-0.356 \\
(0.269)\end{array}$ & $\begin{array}{l}-0.368 \\
(0.242)\end{array}$ \\
\hline Military presence & $\begin{array}{l}0.114 * * * \\
(0.018)\end{array}$ & $\begin{array}{l}0.145 * * * \\
(0.019)\end{array}$ & $\begin{array}{l}0.119 * * * \\
(0.024)\end{array}$ & $\begin{array}{l}0.130 * * * \\
(0.029)\end{array}$ \\
\hline U.S. border & $\begin{array}{l}-1.844 * * * \\
(0.268)\end{array}$ & $\begin{array}{l}-1.757 * * * \\
(0.289)\end{array}$ & $\begin{array}{l}-1.050 * * * \\
(0.360)\end{array}$ & $\begin{array}{l}-1.575^{* * * *} \\
(0.486)\end{array}$ \\
\hline Economic inequality & $\begin{array}{l}3.581 * * \\
(1.741)\end{array}$ & $\begin{array}{l}2.383 \\
(1.915)\end{array}$ & $\begin{array}{l}9.200 * * * \\
(3.286)\end{array}$ & $\begin{array}{l}6.655 * * \\
(2.760)\end{array}$ \\
\hline Economic development & $\begin{array}{l}-0.658 * * * \\
(0.095)\end{array}$ & $\begin{array}{l}-0.553^{* * *} * \\
(0.116)\end{array}$ & $\begin{array}{l}-0.834 * * * \\
(0.194)\end{array}$ & $\begin{array}{l}-0.615^{* * *} * \\
(0.175)\end{array}$ \\
\hline Population & $\begin{array}{l}0.144 * * * \\
(0.046)\end{array}$ & $\begin{array}{l}0.085^{*} \\
(0.045)\end{array}$ & $\begin{array}{l}0.061 \\
(0.044)\end{array}$ & $\begin{array}{l}0.091 * * \\
(0.041)\end{array}$ \\
\hline Constant & $\begin{array}{l}-8.645^{* * * *} \\
(0.870)\end{array}$ & $\begin{array}{l}-8.587 * * * \\
(1.041)\end{array}$ & $\begin{array}{l}733,289.214 \\
(0.000)\end{array}$ & $\begin{array}{l}2166741 * * * \\
(1.194)\end{array}$ \\
\hline Observations & 8,119 & 8,119 & 8,119 & 8,119 \\
\hline
\end{tabular}

Standard errors clustered by municipality shown in parentheses. ${ }^{*} p<.10, * * p<.05$, $* * * p<.01$. 


\section{Notes}

Acknowledgments: We thank Karina Aguilera, Mylene Cano, and Omar Espejel for research assistance.

${ }^{1}$ Hoffman $(2006,36)$ argues that a crucial distinction between terrorists and criminals is that "the criminal is not concerned with influencing or affecting public opinion."

${ }^{2}$ One exception is research on graffiti, discussed below.

${ }^{3}$ There is no consensus term for this phenomenon in English. In Spanish, they are often called narcomensajes, literally narco-messages. The "narco" phrasing is not always technically accurate because perpetrators might be engaged in other illicit businesses, and not only the drug business.

${ }^{4}$ Our quantitative tests analyze 2007-2010, important early years in the violence. We focus on these years because many news agencies stopped reporting on narco-messages in 2011, at the government's encouragement, which introduces challenges for data collection. We discuss this more below.

${ }^{5}$ When we could identify the perpetrator, larger cartels were the most common perpetrators. However, many messages are un-signed, or falsely attributed to others. ${ }^{6}$ Beyond this direct effect of competition with the state, it is also possible there is a longer-term, indirect effect because state actions are likely to lead to more interorganizational competition when groups fragment (e.g., Carpenter 2010).

${ }^{7}$ Criminal groups are frequently covered by the media (Chermak and Chapman 2007). These groups' actions might especially induce coverage if crimes are provocative. The news media can unwittingly help them intimidate their enemies (Durán Martínez 2015a). 
${ }^{8}$ Organized crime may not relate in the same way to different types of media. Most information competition seems to happen at the local level, where journalists are least protected and where more detailed accounts of local crime are regularly reported.

${ }^{9}$ A local market on its own does not necessarily lead to violence. Durán-Martínez (2015b) shows that the level of violence depends on the relationship between local gangs and larger drug-trafficking organizations.

${ }^{10}$ This reporter was not left with a narco-message, or any other way to infer the precise reason for his death. However, the fact that he was a crime reporter is suggestive. Other killings have been more directly related to narco-messages, such as a narco-message in Acapulco that named the partner of a recently-murdered blogger, and accused another news outlet of cooperating with (presumably rival) criminals (Flores Contreras 2018). ${ }^{11}$ Narco-messages frequently appear in incidents involving violence, often as part of a more grisly and symbolic form of communication left at a crime scene. In our dataset, about $70 \%$ of the banners are paired to a homicide.

${ }^{12}$ Another approach would be to gather information on threats or injuries to journalists. This would likely result in under-reporting, as many such incidents are not reported.

${ }^{13}$ We consider this better than using counts of detainees for illicit drug use because our measure does not depend on the willingness/capacity of authorities to enforce the law.

${ }^{14}$ Results are available from the authors. 